\title{
EFEKTIVITAS CENDAWAN ENTOMOPATOGEN BEAUVARIA BASSIANA TERHADAP HAMA PENGGEREK BUAH KAKAO CONOPOMORPHA CRAMERELLA SNELLEN
}

\author{
Yustina M. S.W. Pu'u \\ Program Studi Agroteknologi Fakultas Pertanian Universitas Flores \\ yus_puu@yahoo.com
}

\begin{abstract}
Efectivity of Fungi of Entomophatogen Beauvaria bassiana on Cocoa Pod Borrer Conopomorpha cramerella Stellen.

Cocoa pod borer Conopomorpha cramerella Snellen (Lepidoptera: Gracillaridae) is one type of the key pest which is highly responsible for drilling cocoa, which then causes the production and quality of cacao to decrease. The use of entomopathogenic fungus is one of the alternatives to cope with it. By infecting and developing within insects, such a fungus can cause the insects to suffer from diseases wich will then be responsible for their death. Beauveria bassiana are types of the entomopathogenic fungus which are used for controlling cocoa pod borer, as they are able to infect the pest trough the enzyme or toxin produced, wich then leads to its death. This study aims at effectiveness test of entomopathogenic fungus Beauveria bassiana against cocoa pod borer.

This research was conducted at the Laboratory Udayana University in Bali from May to November 2010. . The experimental design employed was randomized complete block design (RCBD) wich was made up of four treatments such as B0 (Control), B1 (B. bassiana in wich the spore density was $\left.10^{5} \mathrm{spora} / \mathrm{ml}\right)$; B2 (B. bassiana in wich the spore density was $\left.10^{6} \mathrm{spora} / \mathrm{ml}\right)$; B3 (B. bassiana in wich the spore density was $10^{7}$ spora/ml).

The result show that the Larvae CPB which was infected by B. bassiana shows different treatments and responses than control. The fastest death of the larvae CPB took place on the treatment of $B$. bassiana in which spore density $10^{7}$. the fastest appearance of spore took place on the treatment five days after inoculation. The fungus of $B$. bassiana at the spore speed of $10^{5}$ and $10^{7}$ caused all the larvae CPB $100 \%$ to die at five days after inoculation.
\end{abstract}

Key words: Entomopathogenic, Cocoa Pod Borer, Beauveria bassiana.

PENDAHULUAN

Indonesia merupakan Negara pengekspor kakao terbesar ketiga setelah Cote d'lvorie dan Ghana dari Afrika. Propinsi Bali ikut menyumbang ekspor tersebut sejak tahun 2003 sekitar 5,968.11 ton per tahun (Disbun Bali, 2007). Ekspor kakao Bali semakin meningkat seirama dengan perkembangan pertanaman kakao yang tergolong sangat pesat karena meningkatnya permintaan komoditas tersebut dari tahun ke tahun.

Total produksi kakao Bali terus meningkat sampai tahun 2005 yang didukung oleh meningkatnya jumlah tanaman produktif (Supartha, 2008b). 
Namun demikian laju produktivitasnya cenderung menurun di berbagai daerah kabupaten yaitu 6 persen pada tahun 2005 dan sampai 42,71 persen pada tahun 2006. Akibat penurunan produktivitas tersebut diperkirakan petani mengalami kerugian sekitar $3-5$ milyar pada tahun 2004 - 2005 dan sekitar 52,27 milyar rupiah per tahun pada tahun 2006 (Disbun Bali, 2007). Salah satu penyebab utama menurunnya produksi kakao tersebut adalah serangan hama dan penyakit tanaman.

Hama penting yang menjadi penyebab utama menurunnya produksi dan mutu kakao tersebut adalah Penggerek Buah Kakao (PBK) Conopomorpha cramerella Snellen (Lepidoptera: Gracillaridae). Hama tersebut merupakan hama langsung yang menyerang bagian dalam buah. Stadium yang merusak adalah larva, dimana larva ini makan plasenta yang merupakan saluran makanan menuju ke biji sehingga mengakibatkan penurunan hasil dan mutu biji. Biji menjadi kempes (kurang berenas) dan lengket sehingga berpengaruh terhadap kriteria standar mutu biji terutama bean count dan kadar sampah biji yang secara keseluruhan mempengaruhi daya saing dan perlakuan harga. Akibat serangan tersebut, pengiriman biji kakao ke pasar global seperti Amerika Serikat, Eropa dan China sering dikenai biaya tambahan atau potongan harga yang nilainya mencapai 350 dolar Amerika per ton.

Upaya penanganan terhadap hama tersebut sampai saat ini telah dilakukan dengan aplikasi teknologi pengendalian tepadu dengan memadukan cara kultur teknis melalui pemangkasan bentuk, panen sering dan sanitasi (Sulistyowati et al., 1995 dalam Supartha, 2008) serta pengendalian hayati dengan pemanfaatan semut hitam dan
Beauveria bassiana (Wardojo, 1984 dalam Supartha, 2008).

Pemanfaatan musuh alami dari golongan patogen merupakan salah satu alternatif pengendalian hama PBK. Salah satu entomopatogen yang berpotensi dikembangkan sebagai alternatif pengendalian hama PBK adalah Beauveria bassiana. Cendawan entomopatogenik ini mempunyai kapasitas reproduksinya tinggi, siklus hidupnya pendek, relatif aman, bersifat selektif, kompatibel dengan beberapa jenis insektisida dan mudah diproduksi.

Beauveria bassiana memproduksi toksin yang disebut beuvericin. Antibiotik ini menyebabkan gangguan pada fungsi nukleus serangga, sehingga menyebabkan pembengkakan yang disertai pengerasan pada serangga yang terinfeksi. $B$. bassiana juga dapat menginfeksi serangga melalui kontak langsung dan inokulasi atau kontaminasi pakan.

Hasil penelitian melaporkan bahwa, Beauveria bassiana yang diisolasi dari pupa $C$. cramerella di Malaysia dan Maluku dilaporkan mampu menekan serangan PBK sebesar 83,33\%. Penyemprotan $B$. bassiana isolate Bby 725 yang dilakukan pada buah muda dan cabang horizontal berhasil menekan serangan PBK terhadap buah antara 54 $60,5 \%$ (Supartha et al., 2008). Beauveria bassiana juga dapat menyebabkan kematian pada larva dan pupa PBK sebesar $40-100 \%$. Sulistyowati et al., 2002 menunjukkan bahwa penggunaan $B$. bassiana secara terus menerus pada pertanaman kakao tidak berpengaruh buruk terhadap musuh alami maupun serangga berguna lainnya. Untuk dapat memanfaatkan cendawan entomopatogen sebagai bahan dasar agens hayati secara optimal, perlu dilakukan pengujian secara mendalam tentang efektivitasnya terhadap hama sasaran. Sampai saat ini 
informasi tentang efektivitas jamur entomopatogen Beauveria bassiana terhadap hama penggerek buah kakao pada tanaman kakao belum banyak dilaporkan sehingga penelitian ini perlu dilakukan.

\section{BAHAN DAN METODE}

Penelitian ini menggunakan Rancangan Acak Kelompok Lengkap (RAK) dengan 4 perlakuan konsentrasi $\left(10^{5} \mathrm{spora} / \mathrm{ml}\right.$ air, $10^{6} \mathrm{spora} / \mathrm{ml}$ air, $10^{7}$ spora/ml air dan kontrol), diulang sebanyak 5 kali sehingga terdapat 20 satuan percobaan.

Penelitian ini dilaksanakan di Laboratorium Ekologi dan Sistematika Serangga dan Laboratorium Mikrobiologi Jurusan Hama dan Penyakit Tumbuhan Fakultas Petanian Universitas Udayana di Denpasar. Waktu penelitian dimulai dari bulan Agustus sampai November 2009

Bahan yang digunakan dalam penelitian ini adalah isolate $B$. bassiana, serangga PBK, buah kakao, alkohol $70 \%$, alkohol 95\%, kloramfenikol, kain kasa, media PDA, Tween $80 \%$ dan aquabides.

Alat yang digunakan adalah hand sprayer, cawan Petri, tabung erlenmenyer, tabung reaksi, stoples,tabung reaksi, sendok pengaduk, nampan, talenan, pisau, cool box, lup, kertas label, pinset, thermohigrometer, kertas saring, plastic, alumunium foil, kapas, timbangan elektrik, panci, jarum oose, haemacytometer dan laminar flow.

Pelaksanaan penelitian meliputi langkah - langkah berikut :

\section{Pengumpulan larva PBK}

Larva instar 2 dikumpulkan dari kebun kakao yang ada di sekitar Kecamatan Selemadeg Tabanan. Pengumpulan larva dilakukan dengan cara membelah buah kakao yang menunjukkan gejala terserang PBK. Larva-larva yang ada pada buah dikumpulkan dengan menyertakan bagian buah sebagai media dan bahan pakan larva untuk selanjutnya dibawa ke laboratorium dan dipelihara

\section{Perbanyakan B. bassiana}

Perbanyakan dilakukan pada media PDA dengan komposisi 200 g kentang, 20 g dekstrosa, $15 \mathrm{~g}$ agar dan 1 liter aquades. Setelah medium didinginkan kemudian diinokulasikan dengan jamur $B$. bassiana. Medium yang telah diinokulasi kemudian diinkubasi selama 3-5 hari pada suhu kamar $20^{\circ}-30^{\circ} \mathrm{C}$ dan RH $90 \%$ selama 3-5 hari.

\section{Uji efektivitas B. bassiana terhadap Penggerek Buah Kakao (PBK) Conopomuorpha cramerella Snellen}

Untuk pengujian efektivitas $B$. bassiana terhadap penggerek buah kakao $C$. cramerella Snellen yaitu pada setiap perlakuan terdiri dari 10 ekor imago PBK sebagai serangga uji yang dimasukkan dalam stoples, kemudian disemprot dengan suspensi $B$. bassiana sesuai perlakuan pada serangga dan buah kakao. Penyemprotan dilakukan secara merata, mengenai serangga dan buah kakao. Pengamatan dilakukan mulai hari hari ke-2 setelah aplikasi selama 10 hari terhadap kematian imago PBK tersebut.

Adapun Variabel yang diamati adalah :

1. Perilaku dan respon larva terhadap jamur entomopatogen $B$. bassiana Perilaku dan respon larva akibat infeksi jamur entomopatogen dilihat dari gerakan larva, perilaku makan dan perubahan morfologi (bentuk) serta perubahan warna larva PBK.

2. Waktu kemunculan spora pada larva PBK (masa inkubasi) dalam interfal pengamatan setiap hari. 
Waktu kemunculan spora pada masing-masing perlakuan diamati satu hari setelah aplikasi jamur entomopatogen pada larva PBK sampai 10 hari pengamatan (Barson, 1977 dalam Ahmad, 2008)

3. Waktu kematian larva PBK (hari)

Waktu kematian larva diamati setelah aplikasi entomopatogen. Pengamatan dilakukan untuk mengetahui cara kerja (mode of action) dari masing-masing jamur entomopatogen dari awal infeksi sampai menyebabkan kematian pada larva.

4. Persentase kematian larva PBK (\%) Pengamatan kematian larva dilakukan dengan mengamati jumlah larva uji yang mati setelah aplikasi jamur entomopatogen pada satu hari setelah aplikasi sampai 7 hari pengamatan. Persentase kematian dihitung dengan rumus:

$$
P=\frac{a}{b} x 100 \%
$$

dimana :

$\mathrm{P}=$ Persentase kematian

$\mathrm{a}=$ Jumlah larva uji yang mati

$\mathrm{b}=$ Jumlah larva uji yang diamati

Data dianalisis dengan analisis varian. Jika uji $\mathrm{F}$ menunjukkan perlakuan berpengaruh nyata terhadap variabel yang diamati, maka untuk membandingkan nilai antar perlakuan digunakan uji beda nyata terkeci (BNT) taraf 5\%.

\section{HASIL DAN PEMBAHASAN \\ 1. Perilaku dan respon larva terhadap jamur entomopatogen B. bassiana}

Larva yang terinfeksi $B$. bassiana pada awal infeksi menjadi kurang aktif dan lemah, adanya bercak hitam pada kutikula, pada hari ketiga tubuh larva berwarna kehitaman dan mengeras seperti mumi serta permukaan tubuhnya dipenuhi miselia yang berwarna putih Perubahan perilaku dan respon larva PBK tersebut disebabkan karena kerusakan pada semua jaringan tubuh larva yang didukung oleh enzim dan toksin yang dihasilkan oleh jamur entomopatogen tersebut. Ahmad (2008) menyatakan bahwa toksin yang dihasilkan oleh jamur B. bassiana dapat merusak saluran pencernaan, otot, sistem syaraf, pernafasan gangguan pada fungsi hemolimfa dan nukleus serangga menyebabkan pembengkakan dan pengerasan pada serangga yang terinfeksi sehingga serangga mengalami kematian.

\section{Waktu Kemunculan Spora pada Larva PBK (masa inkubasi)}

Hasil analisis menunjukkan bahwa perlakuan entomopatogen $B$. bassiana berpengaruh nyata terhadap waktu kemunculan spora pada larva PBK. Rata-rata waktu kemunculan spora pada hari ke-5 untuk semua perlakuan kecuali kontrol (Tabel 1).

Tabel 1 Waktu kemunculan spora jamur entomopatogen $B$. bassiana pada larva PBK

\begin{tabular}{lc}
\hline \multicolumn{1}{c}{ Perlakuan } & Waktu Kemunculan Spora (hari) \\
\hline B. bassiana $10^{5}$ spora/ml (B1) & $5,0 \mathrm{a}$ \\
B. bassiana $10^{6}$ spora/ml (B2) & $5,0 \mathrm{a}$ \\
B. bassiana $10^{7}$ spora/ml (B3) & $5,0 \mathrm{a}$ \\
\hline Kontrol (aquades) & $0,0 \mathrm{~b}$ \\
\hline Keterangan : angka-angka yang diikuti oleh huruf yang sama pada kolom yang sama pada \\
setiap variabel adalah tidak berbeda nyata pada uji jarak berganda Duncan 5\%; Data \\
dianalisis setelah ditransformasi ke $\sqrt{\mathrm{x}}+0.5$
\end{tabular}


Waktu kemunculan spora $B$. bassiana pada Larva PBK pada semua perlakuan konsentrasi tidak berbeda nyata kecuali dengan kontrol. Peristiwa ini disebabkan karena proses replikasi dan reproduksi jamur dalam tubuh larva sehingga sporanya akan keluar menembus kutikula larva yang didukung oleh suhu dan kelembaban ruangan selama penelitian berlangsung rata-rata $26-30{ }^{\circ} \mathrm{C}$ dan 71-80 \%. Menurut Tanada dan Kaya (1993) mekanisme infeksi jamur entomopatogen pada serangga melalui beberapa tahap yaitu adanya kontak antara propagul jamur dengan tubuh serangga, penempelan dan perkecambahan propagul jamur pada integumen serangga, penetrasi ke dalam hemocul dan perkembangan jamur pada tubuh serangga. Jamur yang berkembang pada tubuh serangga akan mengembangkan protoplas pada hemokul dan membentuk hifa, dan menyebar dengan cepat dengan menghasilkan toksin sebagai bagian dari mekanisme pertahanan dirinya.

\section{Waktu Kematian Larva PBK (hari)}

Hasil analisis statistika menunjukkan bahwa perlakuan jamur entomopatogen $\quad B$. bassiana berpengaruh nyata terhadap waktu kematian larva PBK. Rata-rata waktu kematian larva PBK paling cepat pada perlakuan $B$. bassiana dengan kerapatan spora $10^{7}$ spora/ml dibandingkan perlakuan yang lain (Tabel 2).

Tabel 2 Waktu kematian larva PBK

\begin{tabular}{lc}
\hline \multicolumn{1}{c}{ Perlakuan } & Waktu kematian larva \\
& (hari) \\
B. bassiana $10^{5} \mathrm{spora} / \mathrm{ml}(\mathrm{B} 1)$ & $4,0 \mathrm{a}$ \\
B. bassiana $10^{6} \mathrm{spora} / \mathrm{ml}(\mathrm{B} 2)$ & $3,5 \mathrm{a}$ \\
B. bassiana $10^{7} \mathrm{spora} / \mathrm{ml}(\mathrm{B} 3)$ & $2,0 \mathrm{a}$ \\
\hline Kontrol (aquades) & $0,0 \mathrm{~b}$ \\
\hline Keterangan: angka-angka yang diikuti oleh huruf yang sama pada kolom yang sama pada \\
setiap variabel adalah tidak berbeda nyta pada uji jarak berganda Duncan $5 \%$ Data dianalisis \\
setelah ditransformasi ke $\sqrt{\mathrm{X}}_{\mathrm{X}}+0.5$
\end{tabular}

Waktu kematian yang tidak berbeda pada semua perlakuan menunjukkan bahwa isolat jamur $B$. bassiana yang diuji mempunyai virulensi yang tinggi dalam menyebabkan kematian larva PBK. Virulensi yang tinggi dengan kerapatan spora yang tinggi menyebabkan waktu kematian larva lebih cepat, karena jumlah spora yang dihasilkan dalam jumlah yang banyak sehingga waktu kematian menjadi lebih cepat. Neves dan Alves (2004) mengemukakan bahwa waktu kematian serangga dipengaruhi oleh konsentrasi dan tingkat virulensi dari masingmasing isolat.

\section{Persentase Kematian Larva}

Hasil analisis statistika menunjukkan bahwa perlakuan jamur entomopatogen $B$. bassiana dan $M$. anisopliae berpengaruh nyata terhadap persentase kematian larva PBK dibandingkan dengan kontrol. 
Tabel 3. Persentase kematian larva PBK pada perlakuan jamur entomopatogen $B$. bassiana

\begin{tabular}{lccccccc}
\hline \multirow{1}{*}{ Perlakuan } & \multicolumn{6}{c}{ Kematian Larva PBK (\%) hari ke......... setelah aplikasi } \\
\cline { 2 - 8 } & $1 \mathrm{hsa}$ & $2 \mathrm{hsa}$ & $3 \mathrm{hsa}$ & $4 \mathrm{hsa}$ & $5 \mathrm{hsa}$ & $6 \mathrm{hsa}$ & $7 \mathrm{hsa}$ \\
\hline B. bassiana $10^{3}$ spora/ml (B1) & 0,0 & $0,0 \mathrm{c}$ & $0,0 \mathrm{c}$ & $35,0 \mathrm{c}$ & $55,0 \mathrm{c}$ & $75,0 \mathrm{~b}$ & $90,0 \mathrm{~b}$ \\
B. bassiana $10^{5}$ spora/ml (B2) & 0,0 & $15,0 \mathrm{~b}$ & $45,0 \mathrm{~b}$ & $90,0 \mathrm{~b}$ & $92,5 \mathrm{~b}$ & $100,0 \mathrm{a}$ & $100,0 \mathrm{a}$ \\
B. bassiana $10^{7}$ spora/ml (B3) & 0,0 & $27,5 \mathrm{a}$ & $60,5 \mathrm{a}$ & $95,0 \mathrm{a}$ & $100,0 \mathrm{a}$ & $100,0 \mathrm{a}$ & $100,0 \mathrm{a}$ \\
Kontrol (aquades) & 0,0 & $0,0 \mathrm{c}$ & $0,0 \mathrm{c}$ & $0,0 \mathrm{~d}$ & $0,0 \mathrm{~d}$ & $0,0 \mathrm{c}$ & $0,0 \mathrm{c}$ \\
\hline
\end{tabular}

Keterangan : angka-angka yang diikuti oleh huruf yang sama pada kolom yang sama pada setaip variabel adalah tidak berbeda nyata pada uji jarak berganda Duncan 5\%; Data dianalisis setelah ditransformasi ke Arc $\sin \sqrt{x}$

Mekanisme kematian diawali oleh perubahan perilaku, perubahan bentuk dan warna larva yang disebabkan oleh proses pertumbuhan jamur pada bagian tubuh larva. $B$. bassiana menginfeksi dan berkembang di dalam tubuh serangga dengan mengeluarkan enzim dan toksin yang menyebabkan kerusakan pada fungsi sel jaringan larva sehingga menyebabkan kematian. Menurut Tanada dan Kaya (1993) toksin yang dihasilkan oleh $B$. bassiana yaitu beauvericin, beauveroulit, bassianaliti, isorolit dan asam oksalat dapat merusak saluran pencernaan, otot, sistem syaraf dan pernafasan. Enzim yang dihasilkan seperti protease, lipolitik, amilase, dan kitinase yang akan menghidrolisis kompleks protein dalam integumen.

Jamur entomopatogen $B$.

bassiana pada konsetrasi $10^{5}$ dan $10^{7}$ spora/ml pada 2 hari setelah aplikasi (hsa) dan menyebabkan persentase kematian larva PBK hingga $100 \%$ pada 5 hari setelah aplikasi dan 6 hari setelah aplikasi dibandingkan perlakuan lainnya (Tabel 5.2). Hal ini disebabkan karena kerapatan spora yang tinggi memungkinkan kontak antara konidia dan tubuh larva lebih banyak dibandingkan pada kerapatan spora yang rendah. Keadaan itu memberi peluang yang lebih banyak bagi konidia untuk menempel, berkecambah, berpenetrasi dan berkembang dalam tubuh larva PBK. Selain itu juga disebabkan karena $B$. bassiana mempunyai kemampuan penetrasi yang lebih tinggi yang didukung oleh enzim dan toksin yang dihasilkan selama proses infeksi berlangsung seperti pada saat kontak dengan kutikula dan hemokul. Tanada dan Kaya (1993) mengatakan bahwa patogenesitas jamur entomopatogen dalam menyebabkan kematian serangga diduga terkait dengan kemampuan menghasilkan enzim dan toksin selama berjalannya proses infeksi seperti kontak dengan kutikula dan di dalam hemokul, yang ditunjukkan oleh perilaku serangga yang terinfeksi. Soetopo dan Indrayani (2007) menyatakan bahwa B. bassiana memiliki fase resisten yang dapat mempertahankan kemampuannya menginfeksi inang pada kondisi kering dan kemampuan penetrasinya yang tinggi pada tubuh serangga.

\section{SIMPULAN}

\section{Kesimpulan}

1. B. bassiana efektif mengendalikan hama PBK.

2. B. bassiana dengan konsentrasi $10^{5}$ dan $10^{7}$ spora/ml paling efektif menyebabkan kematian pada larva PBK di Laboratorium. 
UCAPAN TERIMAKASIH

Ucapan terimakasih penulis sampaikan kepada DIKTI Cq. DP2M atas pendanaannya, Pihak Universitas Udayana atas Fasilitasnya dan Pihak Fakultas Pertanian Universitas Flores atas perijinannya.

\section{DAFTAR PUSTAKA}

Alvim, 1979. Cacao, Ecophysiology of Tropical Crops, Alvim., T.T. Kozlowski (Eds.), New York: Aca. Press

Bong, C. L., Ruslan, A., Norlela, H., Fuddin, S. S., Alias, A., Markos, A. 1999. Beauveria bassiana As A Potential Biocontrol Agent Of The Cocoa Pod Borer, Conopomorpa cramerella. Symposium on Biological Control in The Tropics MARDI Training Centre. Serdang. Selangor, Malaysia 18-19 March 1999.

Broome, J.R., Sikorowski, P.P., Norment, B.R. 1976. A mechanism of pathogenicity of Beauveria bassiana on larvae of the imported fire ant Solenopsis richteri. J. Invertebrate Pathology. 28: 87-91.

Commonwealth Micology Institute. 1981. Description of Pathogenic Fungi and Bacteria. England: Commonwealth Mycology Institute.

Dinas Perkebunan Propinsi Bali. 2007. Statistik Perkebunan Propinsi Bali tahun 2004. Denpasar:
Dinas Perkebunan Propinsi Bali.

http://www.dinasperkebunanb ali.info/

Depparaba, F. 2002. Penggerek Buah Kakao (Conopomorpha cramerella Snellen) dan Penanggulangannya. Jurnal Litbang Pertanian. 21 (2): 6974

Deciyanto, S., Reyes, S.G., Santiago, D.R. 2007. Laboratory assay of Beauveria bassiana against Helicoverpa armigera. Proceedings on The $1^{\text {st }}$ International Conference of Crop Security 2005 at Brawijaya University, Malang, September 20th $22^{\text {nd }}, 2005$. p.46-55.

Desyanti., Hadi, Y.S., Yusuf, S., Santoso, T., 2007. Keefektifan Beberapa Spesies Jamur Entomopatogen untuk Mengendalikan Rayap Tanah Coptotermes gestroi WASMANN (Isoptera: Rhinotermitidae) dengan Metode Kontak dan Umpan. Jurnal Ilmu dan Teknologi Kayu Tropis. 5 (2) : 68-77

Gomez, K.A., Gomez, A.A. 2007. Prosedur Statistik Untuk Penelitian Pertanian. (Sjamsuddin E., Baharsjah J. S. Pentj). Edisi ke 2. Jakarta: Universitas Indonesia.

Irianti, A. T. P., Wagiman, FX., Martoredjo, T. 2001. Faktorfaktor yang Mempengaruhi Patogenisitas Beauveria Bassiana Terhadap Bubuk Buah Kopi (Hypothenemus 
hampeii). Agrosains. 14(3) : 285-296

Laba, I. W., Trisawa, I. M. 2006. Keefektifan Beauveria bassiana dan Spicaria sp. Terhadap Kepik Renda Lada Diconocoris hewetti (DIST.) (Hemiptera: Tingidae). Bul. Litro. 17 (2) : 99-106

Lim, G. T. 1984. The behavioural studies on cocoa pod borer Acrocercops cramerella Snellen. Togo: Ninth International Cocoa Research Conference. 539-542

Neves, P.M.O.J., Alves, S.B. 2004. External Events Related to the Infection Process of Comitermes cumulans (Kollar) (Isoptera : Termitidae) by the Entomopathogenic fungi Beauveria bassiana and Metarhizium anisopliae. Journal of the Neotropical Entomol. 33 (1) : 051-056

Oka, I. N. 1995. Pengendalian Hama Terpadu dan Implementasinya di Indonesia. Yogyakata: Gadjah Mada University Press.

Prasasya, A.A. 2008. Uji Efikasi Jamur Entomoptaogen Beauveria bassiana Balsamo dan Metarhizium anisopliae (Metch.) Sorokin Terhadap Kematian Larva Phragmatoecia castanae Hubner Di Laboratorium.http://library.us u.ac.id/index.php/component/ journals/index.php?option $=\mathrm{co}$ m_journal_review\&id=11081 \&task $=$ view
Prayogo, Y. 2006. Upaya Mempertahankan Keefektifan Jamur Entomopatogen Untuk Mengendalikan Hama Tanaman Pangan. Jurnal Litbang Pertanian. 25 (2) : 47-54

Posada., F.J., Fernando E. V. 2005. A New Method to Evaluate The Biocontrol Potential of Single Spore Isolates of Fungal Entomopathogens. Insect Biocontrol Laboratory, Bldg. 011 a , BARC-W, USDA, Agricultural Research Service, Beltsville. Www.

Insectscience.org/5.37/ref/fig ure 1.html. Disidir tanggal 1 Juni 2009. Hal 1.

Puslitkoka, 2004. Panduan Lengkap Budidaya Kakao. Pusat Penelitian Kopi dan Kakao Indonesia. Jakarta: Agromedia Pustaka.

Santosa, 1980. Dasar-Dasar Perlindungan Tanaman (Bagian Ilmu Hama Tanaman). Bogor: Departemen Ilmu Hama dan Penyakit Tanaman Faperta IPB.

Semangun, H. 1988. Penyakit-Penyakit Tanaman Perkebunan di Indonesia, Yogyakarta: Gadjah Mada University Press.

Setiawati., W., Tinny S. U., Bagus K. U. 2004. Pemanfaatan Musuh Alami dalam Pengendalian Hayati Hama pada Tanaman Sayuran. Bandung: Balai 
Penelitian Tanaman Sayuran. Monografi. 24: 24-25

Soetopo, D., Indrayani, I.G.A. 2007. Status Teknologi dan Prospek Beauveria bassiana Untuk Pengendalian Serangga Hama Tanaman Perkebunan Yang Ramah Lingkungan. Perspektif. 6(1): 29-46

Sudiyanto, 1976. Pedoman Bercocok Tanam Cokelat. Jakarta: Dirjen Perkebunan Departemen Pertanian.

Sulistyowati, E., Junianti, Y. D., Mufrihati, E., Wahab, A. 2002. Keefektifan Jamur Paecilomyces fumosoroseus untuk Mengendalikan Penggerek Buah Kakao (Conopomorpha cramerella). Pelita Perkebunan. 18(3): 120-128.

Supartha, I. W., Susila, I W., Bagus, I G N., Wirya, I G. N.A.S., Sudiartha, P. 2006. Pengembangan Strategi dan Teknologi Pengendalian Penggerek Buah Kakao. Dalam Laporan Akhir Demplot Pengendalian Penggerek Buah Kakao dan Pola Integrasi Kerjasama Dinas Perkebunan Propinsi Bali dengan Jurusan HPT Fakultas Pertanian. Denpasar: Universitas Udayana.

Supartha, I. W., Susila, I W., Bagus, I G N., Wirya, I G. N.A.S., Sudiartha. 2007. Teknologi Pengendalian Penggerek Buah Kakao untuk
Meningkatkan Kuantitas dan Kualitas Produksi Kakao. Materi disampaikan dalam Seminar Hasil Kaji Terap Pengendalian PBK dan pola Integrasi. Tahun Anggaran 2006 yang diselenggarakan oleh Dinas Perkebunan Propinsi Bali, tanggal 16 januari 2007. Denpasar.

Supartha, I. W. 2008. Pengendalian Hama Penggerek dan Penyakit Busuk Buah Kakao Secara Integrasi. I M. Mastika \& I W. Susila (Editor). Denpasar: Dinas Perkebunan Propinsi Bali. ISBN 978-979-18979-0-7.

Tan, S. G, Muhamad, R., Gan, Y.Y., Rita, M. 1988. Hexokinase, Malate, Dehydrogenase, Fluorescent esterase and Malic Enzyme Polymorphisms in Cacao Pod Borer, Conopomorpha cramerella (Snellen). Pertanika. 11:7-13.

Tanada, Y., Kaya, H. K. 1993. Insect Pathology. New York: Academic Press. 318-366.

Todorava, S.I., Coderre, D., Vincent, C., Cote, J.C. 2003. Effects of the entomopathogenic fungus Beauveria bassiana on the oblique banded leafroller. Agriculture and Agri-Food Canada. 1p.

Wahyono, T.E. 2006. Pemanfaatan Jamur Patogen Serangga Dalam Penanggulangan Helopeltis antonii dan Akibat Serangannya Pada Tanaman 
Jambu Mete. Buletin Teknik

Pertanian. 11(1): 17-22

Wahyono, T.E., Tarigan, N. 2007. Uji Patogenesitas Agen Hayati Beauveria bassiana dan Metarhizium anisopliae Terhadap Ulat Serendang Xystrocera festiva. Buletin Teknik Pertanian. 12 (1) : 2729

Wardojo, S. 1994. Strategi pengendalian hama Penggerek Buah Kakao (PBK) di Indonesia. Materi disampaikan pada Gelar Teknologi dan Pertemuan Regional Pengendalian PBK di Kabupaten Polmas Sulawesi Selatan, 3-4 Oktober 1994. 5 hlm.

Wessel, M. 1983. "Shade and Nutrios". Cocoa, Eds. G.A.R. Wood., R. A. Lass. Essex: Logman Group Latd.

Zipcode. 2009. Beauveria bassiana. http://zipcodezoo.com/Fungi/ B/Beauveria bassiana. Disidir tanggal 7 Juni 2009 